August 2008

\title{
A Tale of Two Reconciliations: Germans and Jews after World War II and Bosnia after Dayton
}

Maja Catic

Follow this and additional works at: https://digitalcommons.usf.edu/gsp

\section{Recommended Citation}

Catic, Maja (2008) "A Tale of Two Reconciliations: Germans and Jews after World War II and Bosnia after Dayton," Genocide Studies and Prevention: An International Journal: Vol. 3: Iss. 2: Article 6.

Available at: https://digitalcommons.usf.edu/gsp/vol3/iss2/6

This Articles is brought to you for free and open access by the Open Access Journals at Digital Commons @ University of South Florida. It has been accepted for inclusion in Genocide Studies and Prevention: An International Journal by an authorized editor of Digital Commons @ University of South Florida. For more information, please contact digitalcommons@usf.edu. 


\title{
A Tale of Two Reconciliations: Germans and Jews after World War II and Bosnia after Dayton
}

\author{
Maja Catic \\ Brandeis University
}

By comparing the reconciliation between Germans and Jews in the aftermath of World War II and that between Serbs and Bosniaks in post-Dayton Bosnia, this article argues that reconciliation can be a "simpler" affair in some cases than in others. More specifically, reconciliation between victims and perpetrators is more easily facilitated when both parties do not have to live in the same state and imagine themselves as part of the same political community, as in the case of Germans and Jews. By arguing that the success of German-Jewish reconciliation lies, first and foremost, in the fact that victims and perpetrators did not have to live in the same state in the aftermath of genocide, this article challenges the dominant view that the success of German-Jewish reconciliation was due to the "three Rs" of retribution, restitution, and reconstruction. It also challenges the persistent tendency to invoke German-Jewish reconciliation as a model for reconciliation in other post-genocide societies, such as Bosnia. While reconciliation in the GermanJewish case amounted to the establishment of good bilateral relations between two sovereign nation-states, reconciliation in divided societies such as Bosnia is intertwined with, and inseparable from, the project of state and nation building and therefore much more difficult.

Keywords: genocide, post-genocide reconciliation, ethnic politics

Is reconciliation possible between victims and perpetrators in the aftermath of genocide? Under what conditions is reconciliation more likely to occur and under what conditions is it very difficult or unlikely? What implications follow from the likely and unlikely cases of reconciliation for those interested in aiding the process of reconciliation? This paper seeks to provide answers to these questions by referring to two cases of genocide- the Jewish genocide ${ }^{1}(1939-1945)$ and the Bosniak genocide ${ }^{2}$ (1995)—and by focusing, specifically, on elite-level reconciliation.

Since the implementation of peace in Bosnia, starting in early 1996, many observers have invoked the historical experience of justice and reconciliation in the aftermath of the Jewish genocide in order to criticize similar domestic and international efforts in post-Dayton Bosnia. ${ }^{3}$ Such criticism has been based on an idealized version of the West German and German-Jewish experience without a full appreciation of its flaws, or of how many of its aspects are inapplicable to the Bosnian case. Most often, this comparative criticism has had three primary aspects. The first is rooted in a comparison of the extremely successful retribution against those who masterminded the genocide of the Jews at Nuremberg, while the International Criminal Tribunal for the Former Yugoslavia (ICTY) was largely a failure. ${ }^{4}$ The second aspect concerns restitution to the victims. Jews, as victims of genocide, got a state of their own and resources from their persecutors to sustain the newly created state. In comparison, Bosniak victims had to live in the state that still contained their

Maja Catic, "A Tale of Two Reconciliations: Germans and Jews after World War II and Bosnia after Dayton." Genocide Studies and Prevention 3, 2 (August 2008): 213-242. (C) 2008 Genocide Studies and Prevention. doi:10.3138/gsp.3.2.213 
persecutors and their henchmen. Finally, German perpetrators were not only forced to atone for their historical guilt by paying restitution to the Jews but were also made to accept a partition of the German state. In contrast, Serb perpetrators were rewarded by having their wartime state legitimized under the Dayton Peace Agreement and incorporated into the post-Dayton Bosnian state as a powerful sub-state entity. ${ }^{5}$

Those who invoke these comparative claims use them to explain the success of German-Jewish reconciliation in the aftermath of the Jewish genocide and to account for the difficulty in reconciling Bosniaks and Serbs in the aftermath of the Bosniak genocide. All three comparative claims, however, are only partially accurate, and deserve closer scrutiny, a more detailed examination, and appropriate contextualization. Was Nuremberg a Holocaust trial? How does the ICTY, in fact, compare with Nuremberg? Did German mass murderers become midwives of the Jewish state? Were German perpetrators forced to pay reparations to Israel and live in a divided Germany in order to atone for their historical guilt? Answers to these questions have theoretical and practical significance. From a theoretical perspective, what do the commonalities and differences between the two cases suggest about the likelihood of reconciliation between victims and perpetrators in the aftermath of genocide? From a practical perspective, what do these cases indicate about the effectiveness (or lack thereof) of certain policies and strategies aimed at reconciliation?

\section{Justice and Reconciliation}

(1) Societies have pursued a variety of strategies in confronting historical injustices, including genocide ${ }^{6}$ and in dealing with the various impacts those injustices have made upon social and political reconstruction. The choices societies make about how to deal with historical injustices depend on the contexts in which these injustice occurred and how they came to an end. A central element in each instance is the relationship between the victim and the perpetrator. ${ }^{7}$ The following questions are helpful in determining the context of the victim-perpetrator relationship, which powerfully shapes the model of transitional justice in the aftermath of historical injustices: Did the injustices take place during a violent inter-group conflict, in which all sides committed atrocities? Essentially, the question brings up a distinction between civil wars and massacres. ${ }^{8}$ A good example of a civil war in which all sides committed atrocities is the case of Burundi, and, to a certain extent, Bosnia. These examples stand in contrast to one-sided violence that culminates in genocide, like what was committed by the Ottoman Turkish leadership against its Armenian minority.

(2) Under what conditions did the injustices come to an end? Were the victims more or less totally eliminated, as were the Jews in Germany and the Armenians in Ottoman Turkey? Did the victims, or rather their co-nationals/ co-religionists, stop the injustices, as did the Tutsi in Rwanda? Did the perpetrators themselves stop the injustices and under what conditions: Is the situation more like that of the American South, when slavery was ended and when segregation was ended in response to demands from African Americans through the civil rights movement? Or is it more like how apartheid was ended in response to the demands of black South Africans through a negotiated transition to democracy? 
(3) What is the relationship between victims and perpetrators in the aftermath of historical injustices? Do they live in the same state, and what is the power relationship between the two? If victims and perpetrators waged a civil war, did peace emerge after a total victory by one side, with victors decisively managing the state building process and constructing narratives of identity/membership? Were the victors associated with the victim or perpetrator group, or did peace emerge from a negotiated settlement with a commitment to compromise and reconcile by parties to the conflict? What was the role of external actors in ending the conflict and/or in peace building? Were external actors third-party mediators ending a civil war, did they impose a settlement on the warring sides, or did they do so upon the perpetrators?

Strategies used to confront historical injustices have ranged from historical forgetting and denial, through intermediary strategies of amnesty and truth telling, and on to lustration and trials, depending on domestic and regional contexts. Generally, the strategies used in confronting human rights abuses, including genocide, are divided into two broad categories-retributive justice based on legal retribution, namely punishment; and restorative justice, emphasizing truth telling, moral accountability, restitution, and reconciliation.

For the purposes of this paper, I define reconciliation as the process of restoring fractured relationships between groups that have been divided by violent conflict. I focus on relationships at the larger political level rather than the interpersonal level. Perhaps the best way to think about reconciliation is to think of a continuum, and of three ideal-typical points on that continuum. ${ }^{9}$ At one extreme, we have "thin" reconciliation, which implies a resigned acceptance of the relationship between victims and perpetrators for the sake of peace. Former enemies comply with the law instead of killing each other. Under certain conditions, there may be the appearance of "thin" reconciliation, as in cases of externally sponsored peacebuilding where it is difficult to say whether former enemies are complying with the law sincerely or have simply been pressured to do so. Similarly, an overwhelming victory on one side may give the appearance of reconciliation, while it is nothing more than a horrible defeat that could result in calls for vengeance. Moving along the continuum, it is often possible to move beyond "thin" reconciliation toward actual readiness by victims and perpetrators to enter into public policy discussions and formulations, to build on areas of common concern, and to forge principles and compromises with which both or all can live. Often, this form of reconciliation is characterized by what we could call functional integration of the perpetrator and victim groups, which can grow into a form of social solidarity. At the other extreme we have "thick" reconciliation, which is reconciliation manifesting as mercy, forgiveness, apology, a shared comprehensive vision, and mutual healing (as is often associated with truth and reconciliation commissions). ${ }^{10}$ This kind of reconciliation is the hardest to achieve but is also the most desirable. Some authors have argued that reconciliation is a two-level process, with an individual level-comprised of social encounters among individuals citizens, which generate knowledge of the injustice(s) in question-and a societal level, which is generally associated with the public domain, in which institutions representing a group can make public acknowledgment of crimes committed in the name of that group. Reconciliation carries an imperative to know, which is the responsibility of individual citizens, and to acknowledge, which is the responsibility of officials in the public domain. It is not the lack of forgiveness on behalf of the victims but the "culture of denial" associated with the perpetrators, which is the largest obstacle to reconciliation. 


\section{Germans and Jews}

German-Jewish reconciliation is often invoked as a case of successful reconciliation, and as a model that ought to be emulated. In much public imagining, the success of the German-Jewish reconciliation stems from three factors: retributive justice, namely the trial of top Nazi leaders at Nuremberg, including those directly responsible for carrying out the Final Solution as well as the Auschwitz trials in 1965; restorative justice, namely reparations to Jewish victims and to the State of Israel; and, reconstruction, referring to the transformation of Germany based, among other things, on a successful "mastering of the past."

However, I argue here that the German-Jewish case suggests that this sort of reconciliation between victims and perpetrators is only possible when, in the aftermath of genocide, victims and perpetrators do not have to live in the same state and when they are not facing the challenge of imagining themselves as part of the same political community. The German political transformation in the aftermath of World War II was successful largely because Germany was Judenrein. The facts that Jews were a small minority in the German Reich that the cleansing of the Jews - through (in)voluntary departure or murder-was more thorough than in other genocidal events and that most survivors chose not to live in Germany after the genocide, imply the lack of a significant Jewish presence that would have challenged Germany's political transition. ${ }^{11}$ Two examples stand out. In terms of the formulation of public policy-policies on prosecuting Nazi crimes, on amnesty (1949), and on rehabilitation and pensioning of the former Nazi bureaucrats ${ }^{12}$ — work could proceed more or less unchallenged during the period of Adenauer's "normalization" of German politics. In terms of the reformulation of German identity in the aftermath of World War II, it is true that the previous aggressive nationalism was abandoned, but the more or less cohesive German national identity that emerged afterwards was not one based on constitutional patriotism but on the narrative of German victimization. This new identity would have been complicated had a significant number of the victims of the Holocaust remained in Germany.

But this still does not explain the whole story (if it did, it would be immediately challenged by the Armenian case). So, what were the additional factors necessary in this instance to facilitate reconciliation between victims and perpetrators?

One factor is that the perpetrators themselves must be defeated, ideally by a third party, as the Germans were by the Allies, and that the peace imposed is not a Carthaginian peace. ${ }^{13}$ The importance of Allied victory in Germany was two-fold: first, top Nazi leaders were captured, tried, and punished, and the retributive justice meted out by the Allies was largely formulated with an eye on future prevention rather than vengeance (although vengeance was an important element); and, second, Allied victory was conceived in much broader terms, and went beyond military victory. It implied a victory of democracy over authoritarianism and aggressive nationalism-hence, demilitarization went hand in hand with the decartelization of the economy and the de-nazification of German politics and society.

The other important factor is the presence of a sizable democratic opposition within the perpetrator group. In Germany, this group consisted of Weimar democrats, resistance survivors, and returning émigrés. The democratic opposition could invoke the German tradition, marginal as it was, of democracy and use it as the basis of post-World War II transformation, in contrast to a narrative of imposed democratization that could be seen as illegitimate. This factor, in fact, explains why even when Allies made it clear that they would not be pushing for reparations to the 
Jews and Israel, and when the acceptance of Germany as a partner in the EuroAtlantic bloc under the conditions of the escalating Cold War did not hinge upon German reparations, Germany agreed to pay reparations. Given these particular conditions, reconciliation between Jews and Germans was successfully internationalized.

\section{Nuremberg}

The main elements of transitional justice in post-World War II Germany were determined in the context of the victor-vanquished relationship in an interstate war of aggression. Retributive and restorative measures taken to address the crimes of the Nazis were not primarily concerned with genocide (as against the Jews and the Roma) and ethnic cleansing (against Slavs) but with crimes of aggression and crimes against peace. Given the nature of the genocide against the Jews, and their nearly total extermination from Germany and Europe at large, restorative measures did not focus on the restoration of the victim-perpetrator relationship. Rather, they centered largely on the restoration of Germany as a democratic state incorporated into the political, economic, and military structures of the West: a focus significantly shaped by the newly emerging geopolitical reality of the Cold War.

Nuremberg was created as the result of "unswerving political will on the part of the Allies," which came not from some abstract commitment to humanity at large but was underlined by two self-interested considerations. First, America and Britain, the two countries that played major roles in deciding what Nuremberg would be, saw themselves as the victims of German criminality, and so were focused far more on the criminality of Nazi aggression than on the Holocaust. Second, the Allied decision to get Germany's unconditional surrender and the commitment to occupy Germany militarily meant that there would be few additional risks to Allied soldiers in arresting Nazi war crimes suspects. ${ }^{14}$

The charges that were of greatest interest to the United States were those that bore directly on the United States - the German instigation of World War II-and the prosecution of German leaders at Nuremberg focused on the crimes of aggressive war. ${ }^{15}$ In the words of Hartley Shawcross, Britain's prosecutor at Nuremberg, "The Americans [were] primarily concerned with establishing that the prisoners conspired together to wage a war of aggression-a very vital part of the case." ${ }^{16}$ That crimes against humanity involving genocide were tried by the International Military Tribunal (IMT) at Nuremberg was a great innovation by the IMT, insofar as the prosecution of crimes committed by nationals of a state against their fellow citizens had traditionally been left to the authorities of the nation whose citizens have been so abused. ${ }^{17}$ However, while the prosecution at Nuremberg used the term "genocide" in the indictment, the new offense appeared as a war crime and not as a crime against humanity. ${ }^{18}$ Thus, the Nazi genocide was not conceptualized as a violation of the law prohibiting genocide, but as belonging to a more general category that applied to a wide variety of state acts including, but not limited, to mass murder and extermination. War crimes were the most serious offense possible under the IMT, and with minor exceptions, it included crimes against humanity within its ambit. Nuremberg was staged with an eye toward rendering justice but also clarifying the historical record. The fact that the final solution ${ }^{19}$ was treated as a subset of war crimes compromised the IMT's pedagogic efforts, and contributed to the serious shortcomings in the historical understanding of the Holocaust that emerged from Nuremberg. ${ }^{20}$ It was not until the Holocaust trials, as they were popularly called, in 
the 1960s that the tragedy of Jewry as a whole became the central concern. In fact, much of the Israeli motivation for bringing Eichmann to stand trial in an Israeli court was a sense that the Allies had not paid sufficient concern to the Holocaust at Nuremberg. ${ }^{21}$ These shortcomings were addressed throughout the Eichmann trial, which, according to Lawrence Douglas, actually served to "create the Holocaust," by transforming it from an accessory to Nazi aggression into an episode of worldwide historical significance and made it part of collective memory. However, even at that time, when the Nazi genocide of the Jews was at the center of the judicial processes in West Germany, all Nazi crimes tried in German courts were prosecuted under ordinary statutory law, without the concepts of war crimes, genocide, or crimes against humanity. ${ }^{22}$

The significance of Nuremberg (and other Allied war crimes trials) for the West German Nazi trials was the way that the Allies, and especially the Americans, tried to deploy such criminal trials as part of a broader project to transform Germany from an authoritarian and militarist state into a democratic one. The Allies might have legitimately hoped that justice would prevail and that truth would emerge at Nuremberg, but there was no reason to even ponder reconciliation between victims and perpetrators. Given the choice of the legal framework in which the unprecedented atrocities of the Holocaust were constructed at Nuremberg, and the fact that the Nuremberg trials were not generally well received by the Germans, the historical understanding of the Holocaust in West Germany during the first decade or so following World War II was nearly absent or seriously distorted. But, whether or not the historical record of the past injustice existed, and regardless of whatever form it assumed, the nature of the Nazi genocide against the Jews meant that reconciliation between victims and perpetrators, no matter how "thin" the concept of reconciliation pursued might have been, was not a precondition of post-World War II German state building and democratization.

\section{De-nazification}

De-nazification was a central war aim of both the Allies and the regime's anti-Fascist opponents in the resistance or in exile. Following the Allied occupation, the policy of de-nazification was implemented and focused on the dismantling of the Nazi Party and its organizations, the dissolution of all Nazi institutions, and the prohibition of Nazi propaganda. In the long run, as a result of this sometimes controversial policy, the continued existence of Nazism was effectively prevented, as prominent Nazis were essentially eliminated from public life and Nazism as an ideology was thoroughly discredited, in part as a result of the Nuremberg trials. However, the story of denazification is not a story of a politically uncontroversial and morally unambiguous process. "Amnesty fever," which swept Germany in the late 1940s and the early 1950s and sought not only to end the threat of further prosecutions of former Nazis but to overturn the results of prior convictions as well, was of a piece with the reception of the Nuremberg trials in Germany. ${ }^{23}$ Many Germans objected to the form taken by the Allied trials, and particularly to the facts that Nuremberg was based on ex post facto law-such as the charge of crimes against humanity, which did not exist at the time of Nazi crimes-and that the judges had been appointed exclusively by states which belonged to the winning side in the war. ${ }^{24}$ It is hardly surprising that, once Germany was freed of Allied supervision, and could deal with Nazi crimes as it saw fit, the Bundestag formally annulled the criminal categories used by the IMT, especially 
crimes against humanity, as well as the sentencing guidelines-specifically the death penalty-contained therein.

The process of de-nazification consisted, in essence, of two parallel and related processes: (a) the removal of Nazi officials from public life and the dismantling of Nazi institutions, and (b) the renunciation of Nazi ideology, and, particularly, of official, racist anti-Semitism. Neither was very successful in the short run, as the Auerbach and Hedler affairs helped to demonstrate. In 1952, Philip Auerbach, the leader of the Jewish community in Bavaria and who served in the Bavarian government as administrator for reparation to former Nazi victims, came under investigation for having falsified reparations claims. The Auerbach affair opened a Pandora's box of anti-Semitism and recriminations: several of the prosecutors and judges handling the case had been members of the Nazi Party and Nazi organizations, and rumours of bribery and missing evidence circulated, culminating in the resignation of the Bavarian justice minister. ${ }^{25}$ At around the same time, Wolfgang Hedler, a Bundestag deputy from the right-wing German Party and a former Nazi, was prosecuted for his anti-Semitic and pro-Nazi remarks. He was initially found not guilty of libel or incitement to violence, and it came to light that two of the three judges in the original hearing were former Nazis. ${ }^{26}$

\section{New German Identity}

De-nazification was only one aspect of the larger challenge of breaking with the radical nationalism that was more deeply anchored in German culture than National Socialism. ${ }^{27}$ The combined effect of the Allied partition of Germany and the demonstration of German powerlessness in the face of occupation, on the one hand, and the Allied program for reorientation in the media, schools, and culture on the other, laid the ground for renunciation of radical nationalism after 1945 . The re-examination of the Nazi experience, shaped by de-nazification and Nuremberg, led the Germans to re-examine, on their own terms, the nationalism that lay behind the Nazi experience. As Konrad Jarausch writes, "[I]n the end, support for genocidal Nazism, which had endured far too long, could not but discredit more moderate forms of nationalism that were based on older, secondary virtues." ${ }^{28}$ An important role in this endeavour belonged to Germany's own intellectuals and democratic leaders, and particularly to Kurt Schumacher, Theodor Heuss, Konrad Adenauer, and Ludwig Erhard. $^{29}$

However, the retreat of nationalism and the collapse of the nation as the major reference point in Germany after 1945 did not mean the disappearance of German identity and the construction of the civic nation along the lines of "constitutional patriotism." A certain sense of ethnic solidarity survived the defeat, and a new German identity, constituted by survivors of occupation and captivity who saw themselves as victims, emerged. The "German nation," tarnished by Nazi racism and aggressive nationalism, was transformed into a "community of destiny" based on a defensive resentment toward "the awful things that have been done to the German people."30 However, the legitimacy of the idea of German victimization and its influence on shaping a "policy for the past" benefiting a German majority over a persecuted minority can only be understood in the context of a Judenrein Germany. A surviving, viable Jewish community in Germany, through its very presence, let alone its active contestation, would have challenged both sets of German claims to victimizationthose based on actual suffering (bombing and expulsions), and those on false claims to victim status based on the experience of "harsh" and "unjust" de-nazification and 
"military conviction" especially. Beyond these challenges to the articulation of a common German identity in the symbolic realm, the presence of a viable community of victims of Nazism would have represented significant challenges in developing state policies and legislation, starting with the Amnesty Law of 1949 and the rehabilitation and pensioning of the "131ers." In essence, the surviving Jews, according to Moses Moskowitz, an official working for the US Office of the Military Government, were "the accusers who haunt the Germans and will continue to haunt them until the thousands or millions of individual Germans who had a personal part in the extermination of the Jews are brought to justice."31

In the aftermath, and largely in reaction to the Allied policies of de-nazification and punitive trials, the Federal Republic of Germany under Chancellor Adenauer re-oriented itself toward a policy of economic reconstruction, political democratization, the reintegration of former Nazis, and restitution to Jewish survivors. With large portions of the population, including former Nazis in the judiciary, opposing "any serious efforts at postwar judicial reckoning or frank public memory," forcing the Germans to face the Nazi past would have been both difficult and dangerous. ${ }^{32}$ However, the abandonment of a judicial confrontation with the crimes of the Nazi past during much of the 1950s gave way to juridification of the Nazi legacy in West Germany in the 1960s, mostly through the concept of "Auschwitz on trial." Demands for Germans to confront Germany's Nazi past came from a new generation of Germans, whose reactions to the Holocaust were coupled with demands for radical social and political change. $^{33}$

In order to understand the major reorientation of West German policy in the aftermath of the Nuremberg interregnum, it is necessary to give due consideration to the effects of Cold War, with its shifting alliances and emphases. The Cold War was an important enabling factor, although not the source of, Chancellor Adenauer's policy of integration. Adenauer focused on integration at both the domestic and the international level. On the domestic level, integration consisted of giving those closely associated with the former regime a stake in the new system, while it consisted of integrating West Germany into a larger Western Alliance on the international level. The source of the policy of integration is to be found in West German electoral politics, namely in the lack of an electoral majority supporting policies of active de-nazification and retributive justice. Alienating a significant part of the electorate that was opposed to further trials and active de-nazification could have encouraged nationalist responses in West Germany: something that both Adenauer and the Americans feared. The onset of the Cold War enabled Adenauer to articulate his policy of integration as both a backward- and forward-looking strategy aimed at countering a totalitarian threat in Europe-backward-looking by virtue of its emphasis on preventing the revival of Nazism in Germany, and forward-looking by virtue of its emphasis on containing the Soviet Communist threat. Given the balance of power considerations the containment of the Soviet Union demanded, the United States needed West Germany as an ally more than it needed West Germany to carry out thorough de-nazification and further trials or to pay restitution to Jews.

\section{Wages of Guilt: Reparations and the Holocaust Trials}

Although demands for German reparations to the Jews in the form of compensation for property and monies taken from them had been advanced since 1939, it was not until 1944, when the extent of Nazi destruction of European Jewry became discernible, that the call for collective reparation to the Jewish people came to be heard loudly 
and clearly. The State of Israel itself submitted a claim in 1952, and its most important features originated in two works that focused on post-war Jewish claims-the Moses and Robinson proposals ${ }^{34}$-and included the following: the Jewish collective claim as an innovation in international law, the collective claim regarding heirless Jewish property and with respect to the damage inflicted on the Jewish people, payment of compensation by Germany in the form of commodities for the development of Palestine, and the establishment of a Jewish umbrella organization to represent world Jewry in its claims for reparation from Germany. Originally, both the Moses and Robinson proposals were concerned with restoration, which was narrowly defined as "restoring Jewish life to what it had been before the Jews were subjected to discriminatory treatment." Both were unaware at the time of the scale and nature of the European Holocaust. At the November 1944 Conference of the World Jewish Congress in Atlantic City, an agreement was reached among representatives of Jewish communities and agencies that Germany should be obligated to pay indemnification to the Jewish people and the funds retrieved should be used for the development of Palestine as the only viable solution to the Jewish problem. ${ }^{35}$ Initially, the strategy of Jewish agencies formulating claims on Germany was to get the Allies to pressure Germany to comply through numerous types of attempts. ${ }^{36}$ This changed, however, after Americans made it clear that they were prepared to exert their influence over Germany in the course of bilateral negotiations, but not to claim restitution from Germany for Israel. ${ }^{37}$

The only positive response to Jewish claims for reparations came from Germans themselves, although responses came initially from the Socialist Democratic opposition rather than the ruling Christian Democrats. The first German leader to declare that Germany must pay reparation to the Jews for material loss and injury inflicted on them by Nazi Germany was Kurt Schumacher, in his speech in San Francisco in October 1947. Two years later, the newly appointed Chancellor of West Germany, Konrad Adenauer, made his first public declaration on the Jewish question and his attitude to Israel in November 1949. Adenauer's declaration touched upon the most important elements of the reparation issue that were later involved in subsequent negotiations between Germany and Israel. First, Adenauer pointed out that the German people were determined to atone for the horrors committed against the Jews in their name by a criminal regime. Second, he announced his government's commitment to integrate Jews as equal citizens and guarantee their political, economic, and social rights in Germany. ${ }^{38}$ And third, regarding reparation, Adenauer suggested that the Federal Republic of Germany make reparation for the economic injury inflicted on the Jews by assisting Israel as the most important refuge for the Jewish people. ${ }^{39}$

Negotiations between West Germany, the State of Israel, and Jewish organizations began after Adenauer acceded to the Israeli government's demand for a global claim for German reparations to the Jews, addressed not to him but to the Allies in a Note presented in March 1951. ${ }^{40}$ Adenauer's decision to respond to Jewish claims was prompted by personal and moral imperatives that faced him as a devout Catholic and a democrat who viewed the Nazi actions against the Jews as a crime and wanted to atone for them, and who saw the settlement with the Jews as a precondition for Germany's rehabilitation. In September 1951, at the Bundestag session, Adenauer made his historic declaration on the restitution of property and the payment of indemnification. Most significantly, the declaration recognized that unspeakable crimes had been committed in the name of the German people against the Jews and that the Federal 
Republic of Germany accepted responsibility for the crimes of the Third Reich. Consequently, moral and material reparation had to be made for both the losses and the hardships endured by the Jews, and Adenauer expressed the government's readiness to work together with Jewish representatives and of the State of Israel in seeking a solution to the problem of reparation. ${ }^{41}$

However, Adenauer's personal ethical and political convictions, no matter how important, were not crucial to formulating his official stance regarding Jewish reparation claims. In fact, Adenauer's policy vis-à-vis reparations must be seen with an eye on what Jeffrey Herf has called "democratization via integration," whereby partial but generous amnesty for minor Nazi crimes in 1949 was granted and formal rehabilitation and reinstatement of Nazi civil servants and police officers proceeded in 1951. The successful effort to internationalize the problem of the Nazi past via reparations to the state of Israel and non-Israeli victims went hand in hand with this policy of "democratization via integration" at home. ${ }^{42}$

Negotiations between West Germany, the State of Israel, and the Claims Conference began in March 1952 in Wassenaar, and lasted, with some interruptions, until September 1952. They culminated in the signing of the Reparation Agreement, the first international agreement signed by Germany as a sovereign state after 1945 . The basis for reparation was not the Nazi persecution of the Jews, as the reparations are often incorrectly remembered, but exclusively for the heirless seized property and material damages. The suffering and murders, as the Jewish negotiators insisted, could not be atoned for. As the President of the Conference on Jewish Material Claims Against Germany, Dr. Nahum Goldmann, argued in response to arguments that direct talks with Germany would erase the stigma of Germany's moral untouchability in the international community: "We are not dealing here with a quid pro quo. Nobody is saying to the Germans: You pay us; we forgive you. We are promising nothing; we are offering nothing. We are simply claiming what is ours, morally and legally."43

\section{Holocaust Trials}

The two most representative Holocaust Trials were the Eichmann trial in Jerusalem (1960) and the Auschwitz trials in Frankfurt (1963-65). When the trial of the major war criminals ended in October 1946, other allied trials followed. The largest and most famous of these were the American trials-twelve in all-that were conducted at Nuremberg between 1945 and 1949. Nazi war criminals tried at these trials were indicted-and in many cases convicted-for committing crimes against humanity and/or war crimes. The paradox of Nuremberg lies in the fact that while it contained a great historical innovation-the recognition of crimes against humanity-the IMT paid insufficient attention to those particular crimes, and especially to the crime of genocide. War crimes and crimes against humanity were only considered in the context of crimes against peace. ${ }^{44}$ The fact that the extermination of the Jews was of relatively little concern to the planners and prosecutors at Nuremberg was the main motivation behind the Eichmann trial in Jerusalem.

The Eichmann trial was to be the first and, in certain respects, only trial of international significance that explicitly focused upon the crimes of the Holocaust, and most specifically upon the genocide of the Jews. ${ }^{45}$ In fact, Israeli law, while borrowing both from the Nuremberg concept of crimes against humanity and the definition of genocide used in the International Convention on the Prevention and Punishment of the Crime of Genocide, created a more restrictive category of offense: crimes against the Jewish people. The first count in the fifteen-count indictment against 
Adolf Eichmann charged the accused with causing "the deaths of millions of Jews" by implementing "the plan of the Nazis for the physical extermination of the Jews, a plan known by its title, "the Final Solution of the Jewish question." ${ }^{46}$ While instrumental in furthering the understanding of the state-implemented extermination of European Jews, the real significance of the Eichmann trial lies in the fact that it was a vehicle for the social recognition of the victims' suffering. Moreover, the trial served two other important functions in Israel's quest for legitimacy. First, it was intended to demonstrate the young state's capacity to try Eichmann (with all that this entailed), including the ability to reinterpret and reshape international law itself. Second, the trial was to underwrite Israel's state and nation building strategies, legitimating the concept of the Jewish state ruled and dominated by a Jewish majority. ${ }^{47}$

The Auschwitz trial, like most trials after the late 1950s in Germany, was a Holocaust trial and concerned at its core with the Nazi genocide of the Jews. Like all West German Nazi trials, it was conducted under ordinary statutory law. Given this legal framework, the Auschwitz trial was as inadequate as a justice mechanism as it was as a truth mechanism. The trial was unable to adequately address the origins of genocidal policy, the phenomenon of state criminality, and the relationship of the larger German society to a "total social event" such as the Holocaust. ${ }^{48}$ Rather, the trial placed too much emphasis on individual responsibility and culpability, culminating in the image of Auschwitz as the murderous outcome of individual actions rather than as a bureaucratically organized genocide. ${ }^{49}$ Moreover, the sentences meted out to the defendants were not only simply inadequate. According to Rebecca Wittman, they distorted the realities of the program of extermination at Auschwitz ${ }^{50}$ insofar as they were meted on the basis of the individual defendants' concrete guilt, not on the basis of their responsibility for their involvement in a bureaucratically organized genocide.

\section{Serbs and Bosniaks (and Croats)}

Reconciliation in the Bosnian case, in contrast to the German-Jewish one, is often seen as rather problematic. With regards to the three factors often cited as central to German-Jewish success, Bosnia does not fare well. In terms of retributive justice, the failure to arrest Radovan Karadzic and Ratko Mladic has been seen as the indicator of the failure of justice, even though many of those indicted for genocide, crimes against humanity, and war crimes have been prosecuted. Restorative justice has also been a disappointment. In light of the recent International Court of Justice ruling, it became clear that victims would not be compensated for their pain and suffering, even though most Bosniaks—and Croats and Serbs as well—did have their damaged or stolen property restored to them under the provisions of the Dayton Peace Agreement. ${ }^{51}$ With regard to the reconstruction of Bosnia, that is, its transformation away from aggressive and exclusionary nationalism and toward consolidation of democracy, post-Dayton developments have not been very encouraging.

These factors are important in explaining the difficulty of reconciliation between victims and perpetrators but are not crucial. The Bosnian case, I will argue, suggests that reconciliation between victims and perpetrators in the aftermath of genocide is very difficult when victims and perpetrators must construct a shared, self-sustainable state and when the state itself-its specific constitutional and institutional form-is seen as a precondition of reconciliation by the victim group. ${ }^{52}$

The facts that the victim group has been a plurality and not a small minority; that the genocide against the victim group, to borrow from Gerard Prunier, was 
"ambiguous" its leaders were putting forth moral-political demands aimed at reconstructing the very state that was contested at the onset of conflict, account for the difficulty of reconciliation and state building in post-Dayton Bosnia.

\section{The Dayton Era}

The large part of the challenge of reconciling victims and perpetrators in post-Dayton Bosnia is the fact that victims and perpetrators have been tasked with constructing a shared, sovereign state. The Dayton Peace Agreement ended the war between those Bosniaks who so insisted on an independent, unitary Bosnian state that they were willing to sacrifice peace for it and those Serbs who so opposed such a state that they decided to fight a brutal war against it. In order to get these two sides, each with such incompatible goals, to agree to a peace settlement, external actors combined their two incompatible visions to produce a blueprint for a post-conflict state. In practice, this meant that the Bosnian state in its historic borders-internationally recognized in 1992-would continue its existence but with a significantly modified internal structure. To many, the new internal structure, based on two constitutionally privileged "entities"- the Serb Republic and the Federation of Bosnia and Herzegovena (a Bosniak-Croat Federation)—legitimized a structure based on aggression, ethnic cleansing, and genocide. Ever since Dayton, the Bosniak political elites have insisted on removing the Serb Republic from the Bosnian constitution and its political structure as a "genocidal entity," and returning either to the pre-1992 form of the Bosnian state or to another kind of unitary model not based on ethnic territories.

Unlike post-war Germany, post-Dayton Bosnia was not being (re)constructed in the context of an allied military victory but in the context of a semi-negotiated elite pact. To the extent that one can draw a parallel between German Nazi leaders and Serb nationalists associated with the radical Serb Democratic Party, the Bosnian case suggests all the difficulties in reconciling victims and perpetrators when those perpetrators are a legitimate party to a peace settlement and a legitimate partner in the power structures of the new state. The success of Nuremberg as a "victors' tribunal" could not be replicated at the International Criminal Tribunal for the Former Yugoslavia since, among other things, external actors (US, NATO) were not willing to sacrifice the lives of their soldiers in order to arrest the indicted war criminals. Moreover, the integration of international efforts that brought the Bosnian parties to Dayton and enabled them to emerge with a comprehensive peace agreement was lost during the initial process of implementation. Particularly problematic was the failure to integrate military and civilian implementation, which, in combination with a decentralized peace implementation model, further stalled the peace process.

Moreover, unlike in Germany, there was no democratic tradition and no democratic opposition to continue in the aftermath of conflict. ${ }^{54}$ The legacy of "Brotherhood and Unity," an important legacy associated with Bosnia's and Yugoslavia's socialist past, was abandoned or seriously contested. Many aspects of Bosnia's socialist past-a period characterized by peaceful inter-ethnic relations and general stability-were being re-examined through exactly the same narratives of victimization and blame that contemporary Bosnia was struggling with. ${ }^{55}$ In fact, the 1990s were seen, in many ways, as a direct culmination of long, epic, national histories: for Bosniaks, it was the latest phase in the long history of de-Ottomanization of the Balkans, characterized by ten genocides against the Bosniaks/Muslims ${ }^{56}$; for Serbs and Croats, the 1990s were the continuation of the struggle for national 
self-determination and unification, which started with the first rebellion against the Ottomans in the early nineteenth century (for the Serbs) ${ }^{57}$ and Jelacic's break with Hungary in the mid-nineteenth century (for the Croats). ${ }^{58}$

The 1992-1995 war in Bosnia was characterized by horrendous war crimes and severe breaches of international humanitarian law, left close to 100,000 citizens of Bosnia and Herzegovena dead, and displaced more than two million citizens inside and outside of Bosnia. That extremely deep senses of grievance remain a decade after the end of war should come as no surprise, given the appalling scale and severity of human rights violations and war crimes committed during the war. The fear of war breaking out in the case that international forces withdraw has remained high. At the end of 2003, every third citizen feared that in the case of international troops' withdrawal, a war might break out in Bosnia and Herzegovina. After some decline, it was back again, in 2005 , to 2003 levels. $^{59}$

While separatist trends have significantly subsided, nationalist trends measured in terms of the most important national interest among the members of the three constituent peoples have remained strong. Among Bosniaks, the most important national interest has been to make Bosnia and Herzegovina a country of equal citizens and peoples, organized as a simple state with state and municipalities only. Croats have more or less abandoned the idea of the Croat Republic of Herzeg-Bosna (their war aim). However, the formation of separate entities for each of the three peoples has remained a strong national interest among the Croats, along with the emerging support for the concept of Bosnia and Herzegovina as a state of equal citizens and peoples. The notion of the Republika Srpska (RS) as an independent country and its merger with Serbia and Montenegro have long been a dominant national interest among the Serbs. However, most recently, the preservation and consolidation of the $\mathrm{RS}$ as a constitutionally privileged sub-state unit of Bosnia has emerged as the new dominant interest among the Serbs. ${ }^{60}$

The multiparty system in Bosnia and Herzegovina is characterized by two reinforcing elements. On the one hand, there is segmented pluralism (highly fragmented, ideological, strongly polarized, and competitively centrifugal), with a relatively large number of political parties among which ethno-national parties remain dominant; on the other hand, there is the so-called "Weimar syndrome," as reflected in the "fragmentation, dysfunctional operation, and inefficiency of democratic forces." Since its inception, political scene in Bosnia and Herzegovina has been dominated, almost without interruption, by the three ethno-national parties that were in government as Bosnia and Herzegovina descended into war. Although a block of political parties with general civic orientations, and with multi-ethnic composition and both social-democratic and liberal orientation, exists, the civic option is fragmented, disharmonized, and open to occasional coalitions with individual national parties. As such, they are unable to attain any major influence over public opinion in Bosnia and Herzegovina. This has especially been the case with the Social-Democratic Party (SDP), while two other "civic" parties-the Party for Bosnia and Herzegovina $(\mathrm{SBiH})$ and the Party of Independent Social Democrats (SNSD)-have increased their share of the vote tremendously. These two parties, however, have maintained platforms in line with the major national interests of two ethno-national electorates-Serbs in the Republika Srpska and Bosniaks in the FBiH. Inter-ethnic coalition arrangements, especially at the state level, have generally functioned with difficulties and suggest a purely formal arrangement. The need to reinvigorate ethnic solidarities at election times precludes new, or endangers existing, inter-ethnic coalitions. ${ }^{61}$ 


\section{War, Ethnic Cleansing, and Genocide}

The literature dealing with the wars of Yugoslav succession, and particularly that on the war in Bosnia and Herzegovina, has produced an array of competing interpretations and understandings. In general, the literature is characterized by two sets of views on the Bosnian war. The first is that the war was a war of Serb aggression, first and foremost, but also of Croat aggression, to a lesser degree. ${ }^{62}$ The second view holds that the Bosnian war was a civil war and an ethnic conflict. Those who support the aggression thesis generally invoke two significant factors: aggressive and expansionist Serb nationalism, historically rooted and culturally conditioned, directed and coordinated from Belgrade, ${ }^{63}$ and/or the role of communist elites who turned to nationalism in order to preserve their power in the face of declining state socialism. ${ }^{64}$ The role of Slobodan Milosevic is usually seen as being connected to either of these two factors, whereby Milosevic and his regime are interpreted as being either the executors of an aggressive and expansionist Serb ideology or as manipulators of collective Serb trauma and of the uncertainties arising from Yugoslav decline.

Those who support the civil war/ethnic conflict thesis stress the existential nature of the conflict for the groups involved and emphasize the central questions at the heart of the Bosnian conflict and war-the questions of whether or not Bosnia should exist as an independent state, and, if it must exist because the international community insists on it, what shape it should take. ${ }^{65}$ They inevitably recognize the role of the regional dimension in shaping the existential character of conflict, including elements of aggression, as is the case in most civil wars and ethnic conflicts. In the words of Susan Woodward,

It is not necessary to argue that the Bosnian war was an act of aggression from Serbia or Croatia aimed at carving up Bosnia to create a greater Serbia or a greater Croatia in order to see that their military and supply support to Bosnian co-nationals fighting for national self-determination (whether as territorial autonomy in Bosnia or secession to join Serbia and Croatia) was sufficient to evoke a defensive response from Bosnian Muslims. At the same time, the pre-emptive recognition of Bosnian independence by the EU and the United States exacerbated the fears of Bosnian Serbs and Bosnian Croats about what it would mean to be subordinated to a Bosnian Muslim majority in an independent Bosnia. ${ }^{66}$

The Bosnian conflict unfolded in the context of a violent dissolution of the Yugoslav state, as claims to self-determination and sovereignty were made in the Bosnian territory. The movements claiming to represent three (that is, four) ${ }^{67}$ fairly old national groups were laying claim to their own state over all or part of the same territory as the others, and the claims seemed to each group to have had substantial legitimacy and some plausible chance of being implemented. ${ }^{68}$ Serb and Croat major national parties championed the ethnic principle and claimed to represent ethnonational Serb and Croat communities in Bosnia, that were linked to their national states, Serbia and Croatia respectively. Bosniak parties claimed to represent two distinct though interrelated communities: Bosnian Muslims (an ethno-national identity) who were renamed Bosniaks, and Bosnians (a civic identity), referring to all citizens of Bosnia irrespective of ethnic_that is, national-identity. Persistent rival claims to political sovereignty intensified the Bosnian conflict, escalated dangerous levels of ethnic cleansing that were used disproportionately by Bosnian Serb armed forces, and culminated in the acts of genocide against the Bosniaks at Srebrenica in 1995. 
Any analysis of post-conflict reconciliation in Bosnia must begin with a discussion of the particular nature and magnitude of the conflict itself, alongside the post-conflict setting. The extent of the war crimes and severe breaches of international humanitarian law committed on the territory of Bosnia and Herzegovina between 1991 and 1995 has still not been confirmed. However, the currently available data indicate that, by 31 December 1995,

- Close to 100,000 Bosnia and Herzegovina citizens had been registered as killed or disappeared during the 1992-1995 conflict. $^{69}$

- More than one million people were refugees in some 100 countries, representing the largest refugee crisis in Europe since World War II, while another million were internally displaced. The process of return to pre-war "homes of origin" has been relatively successful as a result of an externally facilitated return process. About half of all refugees and internally displaced persons have returned to their pre-war homes ${ }^{70}$ (UNHCR data, Ministry of Refugees and Human Rights).

- Systematic and brutal rape, torture, killing, expulsions, and other extremely serious forms of human rights violations had taken place on a massive scale. ${ }^{71}$

- More than 1,600 religious buildings had been damaged, over 1,200 of which were Islamic, including mosques of world-class importance. ${ }^{72}$

- Nearly all the buildings belonging to the Islamic Religious Community on the territory of what is now the Republika Srpska had been destroyed, as were many churches, monasteries, and other religious buildings throughout Bosnia and Herzegovina.

- War conventions had not been respected. Methods and means forbidden by all international humanitarian law or standards were deployed against the civilian populations, including scatter and incendiary bombs, cluster bombs, and snipers, and the shelling of towns, villages, and other population centers, mainly those with mostly majority Bosniak populations. ${ }^{73}$

The effect of the 1992-95 war has been more detrimental for Bosnia's demographics than the effects of two world wars combined, with each group suffering heavy demographic losses. The war caused mass violent deaths and forced migration that have been unprecedented both in volume and in method used to conduct them. Estimates of population losses remain highly controversial, given that earlier estimates were considerably higher, especially in regards to civilian losses in conflict, particularly those of the Bosniaks. Earlier estimates, most notably those conducted by Professor Ilijas Bosnjovic and used by UNDP reports, placed the total Bosniak losses at 157313 (dead, missing, and war-related mortality), or at 7.8 percent of the total Bosniak population in 1991. The recent estimates conducted by the Research and Documentation Center in Sarajevo are considerably lower, citing the total Bosniak losses, both combatant and civilian, of 64036 or 3.3 percent of the total Bosniak population in 1991. However, while demographic losses may still be subject to considerable debate, it is clear that changes in settlement patterns away from ethnically mixed regions and toward ethnically homogenous regions have been unprecedented. The total territory where Bosniaks comprised a majority decreased by $26.5 \%$ while the total territory where Serbs and Croats comprise a majority increased by a total of $10.9 \%$ and $52.7 \%$ respectively. Ethnic territorial concentration in 1991 ranged from 56.6\% in Bosniak-majority areas to 65\% in Croat-majority areas. In 2001 it increased to $79 \%$ for Bosniak-majority areas and $88.7 \%$ in Serb-majority areas. ${ }^{74}$ 


\section{The Quest for Justice: International Criminal Tribunal for the Former Yugoslavia (ICTY) and the International Court of Justice (ICJ)}

To secure a just peace in the aftermath of war in Bosnia, it would have been necessary to reverse much of the gains of ethnic cleansing (and attempted genocide), and to weave throughout the agreement the operation of various mechanisms of justice in order to de-legitimize and remove from power those responsible for the war and the atrocities, and those most likely to inhibit the return process. The external actors at Dayton were faced not only with holding war criminals accountable for the crimes perpetrated in Bosnia, but also with the deeply unsettling possibility of legitimating the way that new political entities were actually being created in the former Yugoslav space in the 1990s, through organized military campaigns, the seizure of territory, murder and expulsion of targeted populations, plunder of property, institutionalization of criminal networks, and reliance on violence in all areas of political life. Laced with unwieldy compromises from its inception, the Dayton Peace Agreement was criticized for violating the basic tenets of international law. Most notably, by legitimating and constitutionally privileging the "entity" carved out of the very state, and to the detriment of the very people against which the crime of genocide was committed, the agreement, it was argued, violated the UN Convention on Genocide which obliges states to prevent and punish crimes of genocide. The peace agreement provided the mechanisms in the form of constitutional statecraft, electoral policies, and international human rights instruments for rectifying political and moral violations associated with war and for achieving the reintegration of the post-conflict state. However, the effectiveness of these mechanisms depended in large part upon the willingness of external actors to commit politically and militarily to their implementation. Such commitment was crucial in the critical period of peace implementation that was the immediate aftermath of Dayton, especially in regards to the arrests of war criminals and the facilitation of refugee return. Without this crucial commitment to strategic implementation of the peace agreement, provisions in the agreement associated with de facto partition trumped those associated with reintegration, and led to further ethnic separation and entrenchment of ethnocratic rule in Bosnia's sub-state units.

In post-conflict Bosnia, the framework for confronting the crimes and human rights abuses associated with the conflict was set during the conflict itself, as the international community, acting through the UN, and the Bosniaks, as the primary victims of the ethnic cleansing and genocide, demanded justice for mass atrocities committed in Bosnia. The International Criminal Tribunal for the Former Yugoslavia was established by Security Council Resolution 827, which was passed on 25 May 1993 in response to serious violations of international humanitarian law. Under Article IX of the General Framework Agreement for Peace in Bosnia and Herzegovina, parties to the DPA were obliged to cooperate-especially with the ICTY - in the investigation and prosecution of war crimes and other violations of international humanitarian law. On 20 March 1993, Bosnia instituted legal proceedings before the International Court of Justice on behalf of the Republic of Bosnia and Herzegovina against the rump Yugoslavia for violating the 1948 Genocide Convention, and namely for committing, aiding, and abetting genocide in Bosnia. Since its founding, the ICTY has charged 161 persons and prosecuted ninety-four for crimes committed on the territory of the former Yugoslavia; forty-eight of those prosecuted have been charged with crimes committed in Bosnia. ${ }^{75}$ In 2005, Slobodan Milosevic died in custody in the Hague, while Radovan Karadzic and Ratko Mladic still remain at large. The failure to 
apprehend and prosecute Karadzic and Mladic has overshadowed much of the important work conducted by the tribunal, including its successful prosecutions and newly established jurisprudence regarding the crime of genocide. ${ }^{76}$ In February 2007, the International Court of Justice finally passed its judgment in the case against Serbia and Montenegro. The decision upheld the earlier ICTY judgments regarding genocide in Srebrenica and found that the armed forces of the Bosnian Serbs were responsible for the genocide. Serbia and Montenegro was found guilty of failing to prevent genocide but not of committing or aiding and abetting genocide.

In general, the Bosniak pursuit of justice has relied on a two-tier strategy which combined retribution (associated primarily with the ICTY) and restitution (associated primarily with the International Court of Justice). In fact, the tier that focused on the International Court of Justice (ICJ) effectively built upon the legacy of the ICTY, and at the same time addressed a number of limitations that retributive justice models, like the one implicit in the ICTY, suffer from. ${ }^{77}$ Specifically, in addition to retribution against those responsible for wartime injustices (institutions as well as individuals), the emphasis of the ICJ case was on the deserved debt vis-à-vis the victims. On the one hand, the suit was to provide reparations for individual victims' injuries and losses. On the other hand, it was to enable the Bosniaks as a victimized group to have restored to them the only state that can guarantee the restoration of their community and their community's long-term survival.

Bosnia's case at the International Court of Justice-primarily a Bosniak case-has been a political case in the sense that rendering justice in this instance was meant to raise important contemporary political questions. The most important question in the Bosnian case, of course, concerned what kind of state Bosnia should be in light of genocide that occurred during the 1992-1995 conflict. This is not to suggest that the only motive behind the ICJ case was political. Moral-political demands in general, and the ones made by Bosniak elites specifically, are demands for justice on an important level in the aftermath of "unspeakable crimes," and the satisfaction of such demands is required by justice. However, these specific demands aimed at the territorialconstitutional re-organization of the state away from the Dayton entity structure that legitimated sub-state units founded during the war are consistent with Bosniak demands for priority and pre-eminence in the Bosnian state, and as such constitute an obstacle to the project of building a shared, sovereign state.

In the post-Dayton period, Bosniak elites have articulated a state-building strategy, which centered to a large degree on moral claims associated with genocide against the Bosniaks. On the one hand, this strategy asserts that Bosniaks as victims of genocide are entitled to restitution and that they have the right to have restored to them the only state that can guarantee the restoration of their community and their community's long-term survival. On the other hand, it argues that the state that was destroyed as a consequence of internationally wrongful actions, aggression, and genocide, ought to be restored. Genocide is used to de-legitimate not only the institutions and territorial delimitation of the Dayton state but the putative right to self-determination of ethno-national minorities, which would be based on a territorial dimension of national identity. The ICJ case has been a central component of this state building strategy.

The ICJ case has been the centerpiece of a state-building strategy pursued by Bosniak elites, aimed at achieving what the Bosniak leaders perceive the Jews to have achieved on the account of the Holocaust-a state of their own, sustained by reparations from the perpetrators, and a historical record and collective memory of 
past events capable of legitimizing such a state, externally and internally, in the present and the future. ${ }^{78}$ The perception that Jews have successfully put their own genocide to good political use informed the decision of Bosniak elites to continue with the case at the ICJ even after the signing of the DPA, and despite indications that the "genocide ruling" was unlikely. ${ }^{79}$ The logic here was simple: Israel, as the Jewish state, was a form of political restitution on behalf of the international community, which not only used the UN to create such a state but which also compelled the perpetrators to admit to committing genocide and to atone, through reparations, for that crime. The perceived lack of ambiguity about who the victims and the perpetrators were in the Jewish Holocaust was something to be desired in the Bosnian case, and something that only a "genocide ruling," rendered at the International Court of Justice, could deliver. The ICJ case has been a vehicle for the particular narrative that cast the events of the 1992-1995 period in a binary mode-victims and perpetrators, peaceful democracy and aggressive nationalism, moral superiority and moral perversity.

The long-awaited judgment passed in February 2007 was a great disappointment for the Bosniaks. The court found that only the events in and around Srebrenica in July 1995 constituted genocide, and that the armed forces of the Bosnian Serbs-not Serbia and Montenegro-were responsible for carrying it out. ${ }^{80}$ By placing responsibility for genocide against the Bosniaks on the heads of the Bosnian Serbs, the court reemphasized one of the most crucial difficulties of the post-Dayton state building project- the fact that the victim group and perpetrator group are required to construct a shared state on the premise that both groups are constituent and state-forming. The success of any state-building enterprise depends upon the state builders' ability to articulate a new narrative that can support a common vision of the state. As Roger Scruton writes,

The reestablishment of a territorial jurisdiction, without which there cannot be a state in the modern sense, requires ... the simultaneous or prior affirmation of a first person plural. Without the bond of membership, obligations to strangers will not be honored, and the law will be regarded as alien" 81

In light of the ICJ findings regarding the responsibility of Bosnian Serb armed forces for genocide against the Bosniaks, Bosniak leaders intensified their attacks on the political institutions of the Bosnian Serbs, and demanded the removal of the RS as a form of broad collective punishment against the Serbs: a "moral victors' justice" imposed on the perpetrators of genocide.

These actions can only further reinforce the notion that the law (in this case, the Dayton Peace Agreement) that established these institutions is not just alien but that it has been imposed against the backdrop of that most serious injustice, genocide. They will also reinforce the difficulty of honouring obligations to ultimate strangers, perpetrators, and henchmen, and will entrench the image of the RS as the embodiment of moral perversity, making it difficult to find consensus on important issues, such as police reform.

The leaders of the Republika Srpska, on the other hand, insist on the fact that the $\mathrm{RS}$, which does not have international-legal personality, was not sued at the ICJ, and that the court's findings regarding its implication in the Srebrenica genocide is not legally binding. While the RS leaders are right about the ICJ findings being not legally binding and generally unable to affect the constitutional-territorial setup of the Dayton state, these findings can, in fact, curb RS secessionist politics. The judgment contains the basis for some future lawsuit, whereby an independent Republika Srpska could be sued for genocide by Bosnia, which would then continue the 
international-legal continuity of the current Bosnian state. Paradoxically, then, one of the most important implications of the ICJ judgment may be that the RS has the greatest interest in Bosnia's political development, since its exit from Bosnia would also mean the beginning of its end. The act of its independence would initiate the destruction of the RS as an independent state, given its responsibility for genocide and its consequent obligation to pay reparations. At the same time, Bosniak elites are faced with a choice between the pursuit of justice as restitution from a state entity found responsible for genocide-an independent Republika Srpska-and the preservation of Bosnia's territorial integrity and political sovereignty. While their preference for the latter is undisputed, they will undoubtedly continue to press for restructuring of the Bosnian state away from the Dayton formula in general and away from ethnofederalization in particular. The refusal of the leaders of the Republika Srpska to acknowledge the responsibility of RS institutions for genocide notwithstanding, the political establishment in the RS, and the prime minister in particular, has been making some important moves towards responding to those aspects of the ICJ judgment which implicate the RS in the Srebrenica genocide. Those moves include increased commitment to arresting war criminals and facilitating economic development of Srebrenica, especially in response to Bosniak demands for a special constitutional-territorial status for Srebrenica in light of the ICJ judgment.

\section{Conclusions}

Reconciliation between Germans and Jews amounted, essentially, to the establishment of peaceful diplomatic relations between two nation-states, West Germany and Israel, rather than on the reconstruction of German-Jewish relations and the integration of German Jews into post-Holocaust Germany. A return to status quo ante in terms of the revival of Jewish communities in Germany and the restoration of German-Jewish relations was not a goal sought by the occupying powers, the new German leadership, or most Jewish groups. More than half of all German Jews (half a million lived in the Third Reich according to the census in 1933) fled Germany between 1933 and 1945, and the fact that most of them did not return to Germany was a function of two factors. On the one hand, the international Jewish position regarding a Jewish presence in post-Holocaust Germany was aligned with the larger Zionist quest for a Jewish state in Palestine populated by displaced Diaspora Jews. On the other hand, neither the Allies nor the democratic German leadership did much to facilitate the return of German Jews to West Germany.

In addition to Nuremberg and de-nazification, the American military government developed social and political activities to combat anti-Semitism and prejudice as part of their program to re-educate the German nation. ${ }^{82}$ Renunciation of anti-Semitism and the development of new German-Jewish relations were two of the main targets of democratic re-education. At the same time, however, the Allies backed Jewish leaders in America, Britain, and Israel in their attempts to liquidate Jewish-owned assets in Germany and use the proceeds to aid Israel. Jewish groups outside Germany controlled ownerless property in Germany, while the existing community there struggled financially.

Nuremberg, de-nazification and restitution were essential not so much for the victims and their survivors as much as they were for the rehabilitation of the young German republic and for its moral and political integration into the West. Chancellor Adenauer's statement to the West German Parliament on 27 September 1951, 
"Reconciliation with the state of Israel and with Jews throughout the world," placed the issue in the context of Realpolitik and international relations:

Recently, world attention has been variously concerned with the position of the Federal Republic with respect to the Jews. Here and there doubts have been raised as to whether, in this significant matter, the new state is being guided by principles that can do justice to the frightful crimes of a previous epoch, and can set the relationship of the Jews to the German people (Volk) on a new and healthy basis. ${ }^{83}$

The prosecution of top Nazi leaders for crimes against humanity and war crimes was undoubtedly an important factor in post-World War II German political transformation, as well as for the incipient German-Jewish reconciliation. However, Jewish victims of the Holocaust would have to wait for the Eichmann trial to witness symbolic retribution against those responsible for the genocide of the Jews. Moreover, the basis for German reparations to Israel was not the Nazi persecution of the Jews but exclusively the heirless seized property and material damages.

Reconciliation between Serbs and Bosniaks (and more generally among all three groups in Bosnia) has been very difficult because victim and perpetrator groups have faced a task of constructing a shared, self-sustainable state, and the groups have held conflicting, perhaps even irreconcilable, visions of the common state. Bosniak leaders have sought a unitary, centralized state in which they would enjoy a large plurality and a rapidly approaching majority because of their higher birthrate and the likelihood that some Serbs and Croats would voluntarily depart for Serbia and Croatia. The Serbs and Croats sought significant degrees of autonomy from the Bosnian state, the former having attained it in the form of a territorially reduced but constitutionally privileged Serb Republic, and the latter being constrained by the uneasy constitutional compromise with the Bosniaks.

A return to the status quo ante in terms of the re-creation of a multiethnic Bosnian society as it existed prior to conflict, ethnic cleansing, and genocide has been a goal sought by both Bosniaks and the external actors intervening in Bosnia. The process of returning refugees and internally displaced persons to their pre-war homes of origin has been central to the re-creation of a multiethnic Bosnia, and many aspects of external intervention have focused on facilitating return. ${ }^{84}$ Despite many obstacles, most notably active opposition from ethnocratic leaders in Serb and Croat-majority areas, half of all those displaced by conflict (a million or so individuals) have returned to their homes. Many who chose not to return have had their property returned to them. For the Bosniak leaders, however, a return to the status quo ante also implies the restitution of a unitary state that disappeared as a result of "genocidal aggression." Reconciliation has been generally seen as possible only when the effects of ethnic cleansing and genocide have been removed, the Serb Republic being the most tangible effect.

Serb leaders, on the other hand, have defended the Serb Republic as a constitutionally privileged entity on the grounds that this kind of ethno-territorial autonomy serves as the best guarantee of inter-ethnic peace and political stability. Their facilitation of the return of refugees-stipulated by the Dayton Peace Agreement-has generally been reluctant, yielding results mostly in response to pressure from external actors. This has been true of the Republik Srpska's cooperation with the ICTY, as well as its implementation of constitutional reform aimed at ensuring equality of all three groups in both of Bosnia's sub-state units. Unlike the paleo-nationalists associated with the wartime Serb para-state led by Radovan Karadzic, many Serb Euro-nationalists in the RS have renounced aggressive 
nationalism and began to focus on economic revival of the RS. This focus on economic revival-especially on investment in non-Serb majority areas in the RS-has been an attempt to de-politicize the entity's troubled past by means of economic development and anti-corruption campaigns aimed at war-time nationalist leaders. While most Serb leaders in the RS no longer deny the massacre in Srebrenica, the dominant Serb discourse equalizes Serb and Muslim suffering, drawing parallels, for instance, between the Muslims of Srebrenica and the Serbs of Sarajevo. ${ }^{85}$

A comparison between German-Jewish and Bosniak-Serb reconciliation in the aftermath of genocide points to a paradox: in situations where victims and perpetrators must live in the same state in the aftermath of genocide, reconciliation is a much more crucial social goal but also much more difficult to achieve. A number of situations in which genocides (or large-scale massacres and communal violence) have taken place and where victims and perpetrators must continue to live together are evidence of this difficulty. Places like Burundi, Rwanda, Nigeria, post-partition India, and Lebanon have continued to be unstable in the aftermath of genocide and/or mass violence, and many have repeated their violent histories. What these societies share are social structures and struggles for power during and after decolonization, in which genocidal struggles function as means of shaping the basic structure and design of the state and society. ${ }^{86}$ The various circumstances under which human rights abuses, including genocides, can occur impose different conditions on the effectiveness of reconciliation processes. ${ }^{87}$ Nonetheless, social and political reconstruction in the aftermath of such injustices requires institutions of deliberate democracy, as well as the cultivation of national unity. When societies are deeply divided along cultural or ideological lines, democratic procedures may be ineffective in resolving social cleavages, religious and ethnic discrimination, and political animosity. In fact, democratic institutions may become grounds in which violent conflict is pursued by other means, perpetuating and intensifying the conflict in the aftermath of massive injustice. To the extent that democratic institutions and cultivation of national unity are essential for reconciliation, reconciliation is a matter that tests the political leadership of a given society. As a society in which victims and perpetrators of massive injustice, although not genocide, have continued to live together in a single state and to nurture democracy and national unity, South Africa can offer a positive lesson in this regard. The trading of concessions-most notably in the realm of prosecution and amnesty-between elites associated with victims on the one hand and perpetrators on the other was crucial to a peaceful transition and to the long-term process of reconciliation. ${ }^{88}$ Of course, the South African experience does seem to suggest that the quest for reconciliation places unreasonable burdens on victims and elites associated with the victim group. The ability of these elites to face this challenge successfully is an important element of successful reconciliation.

In the case of Bosnia, reconciliation is difficult, in large part, because of the intractability of the conflict among Bosnia's groups and the conflict's existential character. The complexity of the three-party ethnic conflict in Bosnia reflects the intensity of a protracted ethnic conflict, which is essentially an identity-driven conflict resulting from an underlying fear of extinction that grows out of the experience of being a vulnerable ethnic group living with memories of persecution and massacres. Any resolution of protracted conflict must meet the security needs of dominant and/or majority groups as well as subordinate and/or minority groups. The insistence by Bosniak elites on the restitution of the political status quo ante-the restitution of the Bosnian state as it existed in 1992-rivals the Serb elites' insistence on the 
"sacredness" of the Dayton constitutional order. Both are obstacles to the process of articulating a social contract among the three constituent nations that would be the basis for the creation of a shared, sustainable Bosnian state. The majoritarian, nationstate model, thought to assuage some of the worst fears of the Bosniak majority, alienates Serb and Croat minorities and renders state legitimization practically impossible. A durable solution to protracted conflict, and one that can serve as basis for successful state legitimization, must satisfy the demands of subordinate (minority) groups for a fair share of political power even at the price of legitimating their nationalist agendas. Providing security with social and political justice as important aspects of state legitimacy will be very difficult, since group relations in post-Dayton Bosnia render the two goals mutually exclusive.

\section{Acknowledgments}

This article is based on a presentation given at the Genocide and Human Rights University Program in the summer of 2007. I am grateful to students and instructors for many valuable conversations about genocide and reconciliation. I am especially grateful to Roger W. Smith for very helpful comments on earlier drafts of this paper. The section on Bosnia is, in part, based on research funded by the SSHRC doctoral fellowship.

\section{Notes}

1. I use the term "Jewish genocide" instead of "Holocaust" in order to highlight the fact that, while the annihilation of European Jewry was the central dimension of the Holocaust, other groups, such as the Roma and disabled people, were also murdered. As my focus is on the relations between Germans (the perpetrator group) and Jews (the victim group) in the aftermath of genocide, I will refer in this paper to the "Jewish genocide" as an event that was part of a larger phenomenon-the Holocaust.

2. The International Court of Justice, following previous rulings by the International Criminal Tribunal for the Former Yugoslavia (the Krstic case), found that the events in and around Srebrenica in July 1995, namely the killing of eight thousand Bosniak men and boys in Srebrenica by the armed forces of the Bosnian Serb parastate, constitute genocide. In this paper I will be focusing on Bosniaks (the victim group) and Serbs (the perpetrator group), although I will elaborate on the difficulty of making these designations in the Bosnian context. I will consider also the role of Bosnian Croats.

3. Three examples are illustrative. US academic and activist Bogdan Denitch wrote in 1996 that, "[i]deally, for real civic life to be possible again in a post-war Bosnia-Herzegovina, there will have to be both warcrime trials and something resembling the de-Nazification processes in Germany and Italy after the Second World War" (Ethnic Nationalism: the Tragic Death of Yugoslavia, London: University of Minnesota Press, 1996, 8). Drawing on parallels between the historical heritages of Serbs and Germans on the one hand, and Bosniaks and Germans on the other, Charles Ingrao argued that "Nuremberg and de-Nazification were essential for the victims and their survivors, as well as for the international community that let the Holocaust happen." Ingrao's remarks were made at a panel commemorating the tenth anniversary of the massacre at Srebrenica at the Museum of Jewish Heritage, entitled "Genocide and Aftermath: Rationalizing the Process of Truth and Reconciliation in Bosnia and Herzegovina" on 13 July 2005. And, finally, Alexander Ivanko elaborated further on comparing Bosnia with Germany: "The Bosnian Serb entity has failed the 'German test.' No program similar to the de-Nazification of Germany after World War II was ever introduced in Srpska. Nor does it seem likely that one is being contemplated. Racist views in line with those of former Srpska president, Biljana Plavsic - sentenced to a pathetically short prison term by the War Crimes Tribunal in 
The Hague-are still considered respectful, even if not advocated too openly. ... Republika Srpska should also institute a de-Nazification program that would start exorcising the population of the demons of hatred still howling in the minds of many." See Alexander Ivanko, "Bosnia: Dayton brought peace. It's time for justice," International Herald Tribune, 3 February 2004.

4. The success of the ICTY (or the lack thereof) is generally measured in terms of its failure to prosecute Ratko Mladic and Radovan Karadzic, rather than in terms of its successfully prosecuted cases. According to William Schabas, the ICTY has done some very significant work in terms of documenting and record-keeping, as well as in terms of jurisprudence pertaining to crimes of genocide, crimes against humanity, and war crimes. On this, see William A. Schabas, "Was Genocide Committed in Bosnia and Herzegovina? First Judgments of the International Criminal Tribunal for the Former Yugoslavia," Fordham Int'l Law Journal 25 (2001): 23. For a good comparison between Nuremberg and ICTY, see Gary Bass. Stay the Hand of Vengeance: The Politics of War Crimes Tribunals (Princeton and Oxford: Princeton University Press, 2000), 147-276.

5. These two sets of arguments are most often invoked by Bosniak elites. They have been especially significant in reference to Bosnia's case against Serbia and Montenegro at the International Court of Justice.

6. I am suggesting that ethnic cleansing and genocide, on the one hand, and oppressive and discriminatory systems like slavery, segregation, and apartheid on the other, are two different kinds of historical injustices, although they are related and are, oftentimes, intertwined.

7. In his analysis of the Armenian genocide, Donald Bloxham discusses the notion of the "interactive dynamic between victim and perpetrator at the political level." Such a dynamic is crucial in understanding the context of genocide but it does not undermine the applicability of the epithet "genocide." See Donald Bloxham, The Great Game of Genocide: Imperialism, Nationalism, and the Destruction of the Ottoman Armenians (Oxford: Oxford University Press, 2005), 209-10. Moreover, the interactive dynamic between victim and perpetrator is also crucial for understanding the challenges of reconciliation in the aftermath of genocide.

8. See Roy Licklider, ed., Stopping the Killing: How Civil Wars End (New York: New York University Press, 1993), 9-10. Massacres committed in the context of civil wars can constitute and have constituted genocide. While it may be useful to separate the criminal aspect of genocide from its political reality in order to obtain more effective international interventions, the political reality of genocide is crucial in its aftermath, especially in the context of transitional justice and reconciliation. Howard Adelman distinguished among three different types of violent conflict that divided people: (a) interstate wars; (b) intrastate wars related to differences between regions, ethnic groups, ideologies, religions, or simple rivalries between two leaders; (c) government wars against part of its own population by attempting ideological or ethnic cleansing or even genocide. According to Adelman, each case requires a different from of reconciliation. See Howard Adelman, "Rule-Based Reconciliation," in Roads to Reconciliation, ed. Elin Skaar, Siri Gloppen, and Astri Suhkre, 287-89 (Lanham, MD: Lexington Books, 2005).

9. See Michael Walzer, Thick and Thin: Moral Arguments at Home and Abroad (Notre Dame, IN: University of Notre Dame Press, 1994).

10. David Crocker has formalized a threefold understanding of reconciliation as "simple co-existence," "democratic reciprocity," and a "comprehensive reconstruction of social bonds between victims and perpetrators." See his "Truth Commissions, Transitional Justice and Civil Society" in Truth v. Justice: The Morality of Truth Commissions, ed. Robert I. Rotberg and Dennis F. Thompson (Princeton, NJ: Princeton University Press, 2000), 99-121.

11. A census published in June 1933 registered 500,000 Jews living in the German Reich (around 1\% of the total population), of whom approximately one quarter were foreign (non-German) Jews. Approximately another 100,000 people who were not registered had at least one Jewish grandparent. Between 1933 and 1945, approximately 270,000 were able to 
leave Germany; more than 165,000 were murdered; about 15,000 survived the camps, and another 2,000 survived underground. In the spring of 1945, as many as 100,000 Jewish survivors (the majority not being German Jews) found themselves among the 11 million uprooted and homeless people wandering throughout Germany and Central Europe. By 1950, the number of Jews in Germany dwindled to 15,000; only 6,000 were German Jewish emigrants or returnees (Yahil 1971, 496-500). Quoted in John Borneman, "Identity, Exile, and Division: Disjunctures of Culture, Nationality, and Citizenship in German-Jewish Selfhood in East and West Berlin," in Jew, Germans, Memory, ed. Michal Bodemann, 132-33 (Ann Arbor: The University of Michigan Press, 1996).

12. On the West German policy of integration, including the amnesties for Nazi criminals (1949, 1953-1954), the reintegration of the "purging victims," the release of the war criminals, and the "131 Law," which ensured the continuity of employment or retirement on full pensions for former Nazi civil servants, see Norbert Frei, Adenauer's Germany and the Nazi Past: The Politics of Amnesty and Integration (New York: Columbia University Press, 1997).

13. The term refers to the outcome of the Punic Wars between Rome and Carthage, in which the Romans imposed a brutal peace treaty demanding total subjugation of the defeated side. The term is used to describe any peace settlement brought about through the total destruction of the enemy and the imposition of very harsh peace terms on the losing side.

14. Bass, Stay the Hand of Vengeance, 149

15. Ibid, 174.

16. Quoted in Bass, Stay the Hand of Vengeance, 174.

17. The category of "crimes against humanity" was first used by British officials in response to the 1915 Armenian massacres. As Bass writes, "[a]s early 1915, British officials sounded all of the themes that are usually thought of as having been born at Nuremberg: individual criminal responsibility of leaders, the importance of due process as it had evolved at home in Britain, and even the notion of crimes against humanity" (114-15). However, during the planning of Nuremberg, the Allies did not remember that they had used the same precise term "crimes against humanity" as early as 1915 (144).

18. IMTI: 44, quoted in Lawrence Douglas, The Memory of Judgment: Making Law and History in the Trials of the Holocaust (New Haven, NJ: Yale University Press, 2001), 67.

19. Americans at Nuremberg adopted the Nazi perpetrators' term for their crime, the final solution. See ibid.

20. Sir Hartley Showcross, the British chief prosecutor, declared that the Nuremberg tribunal would "provide ... an authoritative and impartial record to which future historians may turn for truth." Quoted in Douglas, The Memory of Judgment, p. 2.

21. On the lack of interest in prosecuting the Holocaust, see Bass 178.

22. Devin O. Pendas, The Frankfurt Auschwitz Trial, 1963-1965: Genocide, History, and the Limits of Law (New York: Cambridge University Press, 2006), 12.

23. Pendas, The Frankfurt Auschwitz Trial, 1963-1965, 13.

24. Ibid., 11.

25. Jay Howard Geller, Jews in Post-Holocaust Germany, 1945-1953 (New York: Cambridge University Press, 2005), 208-10.

26. As historian Mary Fulbrook argues, "what is perhaps most striking about the first two decades of the Federal Republic's existence is not only the relatively high degree of continuity in personnel in the higher reaches of many areas of West German life, but also the extraordinary degree of toleration and indeed elevation to high office of men who, if not exactly guilty of war crimes, were at best political opportunists and immoral trimmers." She cites two examples; the first is Adenauer's chief aide in the Chancellery, Hans Globke, the civil servant who wrote the official commentary for Hitler on the Nuremberg Race Laws of 1935. The other is Rudolf Bilfinger, who was associated with the Wansee Conference discussions that coordinated the details of the "final solution," and who held a top position in the administrative court of Baden-Wuerttemberg in Mannheim after the war. See Mary 
Fulbrook, German National Identity after the Holocaust (Malden: Polity Press, 1999), $61-62$.

27. Konrad H. Jarausch, After Hitler: Recivilizing Germans, 1945-1995 (Oxford: Oxford University Press, 2006), 55.

28. Ibid., 58 .

29. For an excellent analysis of the role of Weimar democrats in post-Holocaust West Germany, see Jerffrey Herf, Divided Memory: The Nazi Past in the Two Germanys (Cambridge, MA: Cambridge University Press, 1997), esp. chapters seven and eight.

30. Ibid., 60.

31. Cited in Herf, 204.

32. Rebecca Wittmann quoting Jeffrey Herf. See Rebecca Wittmann. Beyond Justice: The Auschwitz Trial (Cambridge, MA: Harvard University Press, 2005), 27.

33. Pendas, The Frankfurt Auschwitz Trial, 1963-1965, 21.

34. "Jewish Post-War Claims" by Dr. Sigfried Moses and "Indemnification and ReparationsJewish Aspects" by Dr. Nehemiah Robinson, both published in 1944.

35. Nana Sagi, German Reparations: A History of the Negotiations (Jerusalem: The Magnes Press, 1980), 251.

36. Once the war was over, Dr. Chaim Weizman, in the name of the Jewish Agency, sent a letter to the victorious powers in September 1945, demanding restitution, indemnification, and compensation from Germany for the crimes against the Jews. However, the Paris Reparations Conference held at the end of 1945 virtually disregarded all Jewish demands for individual and collective compensation.

37. Sagi, German Reparations, 61.

38. Sagi, German Reparations, 65.

39. Ibid.

40. In December 1949, following Chancellor Adenauer's speech in November, a five-point declaration was issued at the meeting of the World Jewish Congress in New York, demanding from the West German parliament: (a) acceptance of moral and political responsibility for Nazi deeds toward Jews, (b) material indemnification, (c) legislation against anti-Semitism, (d) re-education of German youth, and (e) a check upon nationalistic tendencies in the West German governments. Then, in January 1950, the Israeli government sent an aide-memoire restating Dr. Weizmann's claims of 1945 to the four occupying powers, and it repeated its claims to the four occupying powers again in January 1951. However, in parallel with this limited diplomatic activity, exploratory talks among Jewish, Israeli, and West German officials were taking place, including, most significantly, contacts between Dr. Noah Barou, founding member of the World Jewish Congress, and Dr. Herbert Blankenhorn, Adenauer's chief political adviser. It was Barou who convinced Blankenhorn that speeches admitting the responsibility of the German people for the crimes of the Nazi regime would never be enough, and who convinced Adenauer that Israel ought to be the main beneficiary of collective compensation.

41. Sagi, German Reparations, 71.

42. See Mary Fulbrook, German National Identity after the Holocaust, 49-79.

43. Nicholas Balabkins, West German Reparations to Israel (New Brunswick, NJ: Rutgers University Press, 1971), 94.

44. The Doctors' and Judges' Trials, part of the twelve Allied trials held in the second round at Nuremberg, contained in their indictments the "conspiracy to commit war crimes and crimes against humanity." However, the tribunal largely dropped this count, stating that the charge was beyond its jurisdiction.

45. Douglas, The Memory of Judgment, 97.

46. Ibid., 118.

47. See Yosal Rogat, The Eichmann Trial and the Rule of Law (Santa Barbara, CA: Center for the Study of Democratic Institutions, 1961).

48. Pendas, The Frankfurt Auschwitz Trial, 1963-1965, 293. 
49. Pendas, The Frankfurt Auschwitz Trial, 1963-1965, 292-93; Wittmann, Beyond Justice, 271.

50. Wittman, Beyond Justice, 271.

51. The right of Bosnian displaced persons and refugees to return to their home of origin has been guaranteed under Annex 7 (Agreement on Refugees and Displaced Persons) of the Dayton Peace Agreement. The right to compensation (for the loss of property, not war damages) has also been guaranteed under Annex 7, even though compensation was not seriously countenanced, initially, for those who chose not to return. To date, most displaced persons and refugees have had their pre-war homes restored to them in Bosnia, although less than half have actually returned. For an excellent discussion of the process of return in post-Dayton Bosnia, see Charles B. Philpott, "From the Right to Return to the Return of Rights: Completing Post-War Property Restitution in Bosnia Herzegovina," International Journal of Refugee Law 18.1 (2006): 30-80.

52. Elazar Barkan is one of the few observers who emphasized the difficulty of reconciliation in a post-genocide context where victim and perpetrator groups must construct a shared state. He has argued that "Bosnia is facing an incomparable obstacle. It is a project that has not been tried anywhere else: reconciliation in a situation where we need to think about remixing." Comparing Bosnia with Germany, Barkan said, "Germany has achieved this [reconciliation] over a generation in some very significant ways, but it has done so without encountering the victims. They were in the US, they were in Israel, they were not in Germany. Most Germans have never seen a Jew in person." He argued this point at the Panel on the Tenth Anniversary of the Massacre at Srebrenica, entitled "Genocide and Aftermath: Rationalizing the process of Truth and Reconciliation in Bosnia and Herzegovena," held at the Museum of Jewish Heritage on 13 July 2005. Barkan's argument about the challenge of remixing victim and perpetrator groups being unprecedented, however, is correct only to a point. Ironically, the project that he is referring to was tried in Bosnia itself in the aftermath of World War II, during which acts of genocide were committed against both Serbs and Bosniaks/Muslims. Remixing seems to have been rather successful in Bosnia following World War II, in large part because of the authoritarian context under which it was facilitated.

53. Gerard Prunier, Darfur: The Ambiguous Genocide (Ithaca, NY: Cornell University Press, 2005). The question about whether ethnic cleansing in Bosnia constituted genocide arose at the outset of the war, provoking much legal, political, and scholarly debate ever since. Some exemplary works include, Martin Mennecke and Eric Markusen, "Genocide in Bosnia and Herzegovina" in Century of Genocide: Critical Essays and Eyewitness Accounts, Second Edition, ed. Samuel Totten, William S. Parsons, and Israel W. Charny, 415-49 (New York: Routledge, 2004). Markusen contends that Bosnian Serbs, and on a smaller scale Bosnian Croats, did commit genocide. Mennecke, on the other hand, argues that none of the warring parties committed the crime of genocide. See also, Martin Mennecke and Eric Markusen, "The International Criminal Tribunal for the Former Yugoslavia and the Crime of Genocide," in Genocide: Cases, Comparisons, and Contemporary Debates, ed. Steven L. B. Jensen, 293-359 (Copenhagen: The Danish Center for Holocaust and Genocide Studies); Steven L. Burg, "Genocide in Bosnia and Herzegovina," in Century of Genocide: Eyewitness Accounts and Critical Views, ed. Samuel Totten, William S. Parsons, and Israel W. Charny, 424-33 (New York: Garland Publishing, 1997), 424; Norman Cigar, Genocide in Bosnia: The Policy of "Ethnic Cleansing" (College Station: Texas A\&M University Press, 1995).

54. On Bosnia's problematic democratization, see Steven L. Burg, "Bosnia Herzegovina: A Case of Failed Democratization," in Politics, Power, and the Struggle for Democracy in South-East Europe, ed. Karen Dawisha and Bruce Parrots (Cambridge: Cambridge University Press, 1997) and David Chandler, Bosnia: Faking Democracy After Dayton (London: Pluto Press, 2000).

55. On narratives of victimization, see Ger Duijzings, "Commemorating Srebrenica: Histories of Violence and the Politics of Memory in Eastern Bosnia," in 
The New Bosnian Mosaic: Identities, Memories and Moral Claims in a Post-War Society, ed. Xavier Bougarel, Elissa Helms, and Ger Duijzings (Aldershot: Ashgate, 2007); Paul B. Miller, "Contested Memories: The Bosnian Genocide in Serb and Muslim Minds," Journal of Genocide Research 8, no. 3 (2006): 311-24; Ben Lieberman, "Nationalist Narratives, Violence Between Neighbours and Ethnic Cleansing in Bosnia-Herzegovina: A Case of Cognitive Dissonance?" Journal of Genocide Research 8, no. 3 (2006): 295-309.

56. The first genocide occurred during the time of the Vienna War (1683-1699), the last during the Bosnian War (1992-1995). See Rizah Gruda, "10 Genocida nad BosnjacimaMuslimanima Balkana," Patriotska liga Bosne ii Hercegovine, www.plav.net/hist/genocidi_nad_muslimanima_balkana.htm (accessed June 23, 2008). The Bosniak "genocide discourse" is associated with several Bosniak historians, most notably Mustafa Imamovic, Smail Cekic and Semso Tucakovic, who have argued that the series of genocides against the Bosniaks have included an economic genocide (as land reform in the interwar and postWorld War II periods) and a cultural genocide (through attempts at cultural assimilation and secularization made in the two Yugoslav states). See Ger Duijzings, 150.

57. The most chilling versions of these narratives were provided by General Ratko Mladic and Major Milovan Milutinovic (formerly Mladic's spokesman), who conceptualized Serb actions against Bosniaks in terms of shared entitlement as revenge for the crimes of the Ottoman janissary forces. See Roy Gutman, Witness to Genocide (New York: Maxwell Macmillan International, 1993), x.

58. Croat hard-liners in Bosnia thought of Bosnia with reference to "the historic right of the Croat people," originally violated by the Ottomans, who destroyed the Catholic Kotromanic dynasty, and by the Serbs, who unjustly claimed Bosnia as their land. For some exemplary comment by Croat leaders, see those made by Bozo Raic in a meeting held between Franjo Tudjamn and the delegation of the Croat Democratic Party BiH, 27 December 1991 in Stenogrami o podjeli Bosne, ed. Predrag Lucic (Zagreb: Kulture i rasvjeta, 2005), 99.

59. UNDP, Early Warning System, Annual Report 2003, 65, table xvii; Early Warning System, Annual Report 2005, 79, table xii.

60. On attitudes of $\mathrm{BiH}$ communities toward the Bosnian state, see Gearoid O Tuathail (Gerard Toal), John O'Loughlin, and Dino Djipa, "Bosnia-Herzegovina Ten Years after Dayton: Constitutional Change and Public Opinion," Eurasian Geography and Economics, 47, no. 1 (2006): $61-75$.

61. See Rebeka Kotlo, "Democratic Role of Political Parties," in Democracy Assessment in Bosnia and Herzegovina, Open Society Fund for Bosnia \& Herzegovina, 149-85 (Sarajevo 2006). See also Mirko Pejanovic, Politicki razvitak Bosne i Hercegovine u postdejtonskom periodu [Political Development of Bosnia and Herzegovina in the Post-Dayton Period] (Sarajevo: Sahinpasic, 2005), especially chapter two, "Ethnic or Political Pluralism."

62. On Croat aggression on Bosnia, see Ciril Ribicic. Geneza jedne zablude. Ustavnopravna analiza nastanka i djelovanja Hrvatske zajednice Herceg-Bosne (Zagreb-Sarajevo-Idrija: Naklada Jesenski i Turk-Sejtarija-Založba Bogata, 2000).

63. See Michael A. Sells, The Bridge Betrayed: Religion and Genocide in Bosnia (Berkeley and Los Angeles: University of California Press, 1996); Branimir Anzulovic, Heavenly Serbia: From Myth to Genocide (New York: New York University Press, 1999); Smail Cekic, Agresija na Republiku Bosnu i Hercegovinu: planiranje, priprema, izvodjenje [Aggression on the Republic of Bosnia and Herzegovina: Planning, Preparation, Execution], (Sarajevo: Institut za istrazivanje zlocina protiv covjecnosti i medjunarodnog prava, 2004).

64. Chip Gagnon, The Myth of Ethnic War: Serbia and Croatia in the 1990s (Ithaca, NY: Cornell University Press, 2004).

65. Steven Burg and Paul Shoup, The War in Bosnia-Herzegovina: Ethnic Conflict and International Intervention (Armonk: M.E. Sharpe, 1999); Susan Woodward, Balkan Tragedy: Chaos and Dissolution after the Cold War (Washington, D.C.: Brookings Institution Press, 1995); Sumantra Bose, Bosnia after Dayton: Nationalist Partition and International Intervention (London: Hurst \& Company, 2002); Xavier Bougarel, Bosnia, anatomie d'un conflit (Paris: La Decouverte, 1996). 
66. Susan L. Woodward, "Bosnia and Herzegovina: How Not to End Civil War," Institute on War and Peace Studies, February 1997, Conference Proceedings, Columbia International Affairs Online, 10.

67. The four groups in Bosnia are Bosniaks, Croats, Serbs, and Bosnians. The first three denote ethno-cultural identifies, while the latter refers to a civic, political identity.

68. This is essentially Michael Mann's argument about the escalation of murderous ethnic cleansing. See Michael Mann, The Dark Side of Democracy: Explaining Ethnic Cleansing (Cambridge: Cambridge University Press, 2005), 6.

69. The most recent war casualty numbers in Bosnia come from the research conducted by the Research and Documentation Center based in Sarajevo. In June 2007, the Center released the following numbers: of the 97,207 persons who had been killed or disappeared, as many as 57,523 were directly involved in the war and 39,684 were civilians. In terms of the ethnic breakdown, the majority of victims were Bosniak with 64,036 dead, followed by the Serbs with 24,905, the Croats with 7,788 and "other" at 478. According to Mirsad Tokaca, who led the project, the figure of total casualties could rise by a maximum of another 10,000 due to ongoing research. See http://news.bbc.co.uk/2/hi/europe/6228152.stm (accessed June 5, 2008). See also the International Herald Tribune, "Research shows estimates of Bosnian war death toll were inflated," http://www.iht.com/articles/ap/2007/06/21/europe/EU-GENBosnia-War-Victims.php (accessed June 5, 2008); Nidzara Ahmetasevic, "Justice Report: Bosnia's Book of the Dead," Balkan Investigative Reporting Network, http://www.birn. eu.com/en/88/10/3377/ (accessed June 5, 2008). Earlier estimates ranged from 150,000 (UNDP report) to 250,000 (or even 300,000), numbers most frequently cited by Bosniak leaders.

70. Ministry of Refugees and Human Rights, The Rights of Refugees and Internally Displaced Persons: A Comparative Analysis (Sarajevo, 2005), 47.

71. In February 2001, the International Criminal Tribunal for the Former Yugoslavia convicted three members of the Bosnian Serb Army for rape, torture, and enslavement. The decision marked the first time in history than an international tribunal brought charges solely for crimes of sexual violence against women. The decision also marked the first time that the ICTY found rape and enslavement to be crimes against humanity. See "Bosnia: Landmark Verdicts for Rape, Torture, and Sexual Enslavement, Human Rights News," Human Rights Watch, http://hrw.org/english/docs/2001/02/22/bosher256.htm (accessed June 5, 2008). See also, Beverly Allen, Rape Warfare: The Hidden Genocide in $\mathrm{BiH}$ and Croatia (Minneapolis and London: University of Minnesota Press 1996) and Alexandra Stiglmayer, ed., Mass Rape: The War Against Women in BiH (Lincoln: University of Nebraska Press, 1993).

72. According to Andras Riedlmayer, of 1,706 mosques in pre-war Bosnia, 1,186 were destroyed ( 985 by Serb extremists and 201 by Croat extremists). See Andras Riedlmayer, "From the Ashes: The Past and Future of Bosnia's Cultural Heritage," in Islam and Bosnia: Conflict Resolution and Foreign Policy in Multi-Ethnic States, ed. Maya Schatzmiller (Montreal and Kingston: McGill-Queen's University Press, 2002).

73. For a detailed account, see the written and oral pleadings of the Bosnian legal team at the International Court of Justice, http://www.icj-cij.org (accessed June 5, 2008).

74. Data on the demographic effects of ethnic cleansing in Bosnia come from a study by Ilijas Bosnjovic. See Ilijas Bosnjovic, "Demografska proslost i buducnost Bosnjaka, Hrvata i Srba u Bosni i Hercegovini" [Demographic Past and Future of Bosniaks, Croats and Serbs in Bosnia and Herzegovina] (Forum Bosnae 2006, 35, 75-89). Available in English from the Central and Eastern European Online Library. See note 69.

75. On war crimes committed in Bosnia and processed by the ICTY, see Zlocin $i$ kazna: procesuiranje ratnih zlocina pocinjenih u BiH pred Medjunarodnim krivicnim sudom za bivsu Jugoslaviju, urednik Dario Novalic (Sarajevo: Fond otvoreno drustvo BiH, u saradnji sa Outreach programom Medjunarodnog krivicnog suda za bivsu Jugoslaviju, 2006). 
76. On this, see Schabas, "Was Genocide Committed in Bosnia and Herzegovina?"

77. On the limitations of the retributive justice model, see Mark A. Amstutz, "Restorative Justice, Political Forgiveness, and the Possibility of Political Reconciliation," in The Politics of Past Evil, ed. Daniel Philpott (Notre Dame: University of Notre Dame Press, 2006), 166. On the local effects of the International Criminal Tribunal for the Former Yugoslavia, see Isabelle Delpla, "In the Midst of Injustice: The ICTY from the Perspective of some Victim Associations," in The New Bosnian Mosaic, ed. Bougarel, Helms, and Duijzings, 211-35.

78. The Holocaust and its aftermath remain the main point of comparison by which Bosniaks express their claim for justice. See the following: Marko Zivkovic, "The Wish to Be a Jew: The Power of the Jewish Trope in the Yugoslav Conflict," Cahiers de l'URMIS, no. 6 (2000), http://urmis.revues.org/docannexe329.html (accessed June 5, 2008); Fahrudin Sinanovic, "Jevreji zbog genocida dobili drzavu, mogu li Srebrenicani poseban status?" [The Jews Got a State on the Account of Genocide-Can the Residents of Srebrenica Set Special Status?], Ljiljan 9-16, juli 2004; Enes Karic, "Vrijeme holokausta balkanskih muslimana" [The Epoch of the Holocaust of the Balkan Muslims], Ljiljan 10-17 avgust 1998; Sead Arslanagic, "Genocide nad Bosnjacima vise nece biti mrtvo slovo na papiru" [The Genocide of the Bosniaks Will No Longer Be a Dead Letter on the Paper], Ljiljan 10-17 februar 2003; Haris Siljadzic, "Zrtva i pravo na krik" [The Victim and the Right to Scream], Ljiljan 25. septembar-2. oktobar 2000; Haris Silajdzic, "Mozemo li mi, Jevreji i druge zrtve holokausta zajedno dici svoj glas protesta" [Can We, the Jews, and Other Victims of the Holocaust Raise Our Voice in Protest] Ljiljan 31. Januar-7 february 2000.

79. William Schabas said that, given the ICTY judgments which restricted the term genocide only to Srebrenica events, a genocide ruling by the ICJ was unlikely. From Schabas's lecture at the Genocide and Human Rights University Program, International Institute for Genocide and Human Rights Studies (A Division of the Zoryan Institute) and University of Minnesota, 7 August 2007.

80. Application of the Convention on the Prevention and Punishment of the Crime of Genocide (Bosnia and Herzegovina v. Serbia and Montenegro), Summary of the Judgment of 26 February 2007, http://www.icj-cij.org/docket/index.php?sum=667\&code=bhy\&p1=3\& $\mathrm{p} 2=3 \&$ case $=91 \& \mathrm{k}=\mathrm{f} 4 \& \mathrm{p} 3=5$ (accessed June 5,2008$)$.

81. Roger Scruton, "The First Person Plural" in Theorizing Nationalism, ed. Ronald Beiner (New York: SUNY Press, 1999), 289.

82. Frank Stern, 80n 9-12.

83. Quoted in Mary Fulbrook, German National Identity after the Holocaust, 66.

84. On the relationship between return, justice and reconciliation, see Tone Bringa, "Reconciliation in Bosnia-Herzegovina" in Roads to Reconciliation, ed. Elin Skaar, Siri Glopppen, and Astri Suhrke (Lanham, MD: Lexington Books, 2005), 187-201.

85. In July 2000, the RS Prime Minister Milorad Dodik acknowledged that a "mass crime" had been committed in Srebrenica (Balkan Crisis Report in Duijzings). Only in July 2003, however, did a high level RS official (Prime Minister Dragan Mikerevic) attend the Srebrenica commemoration ceremony in Potocari (Duijzings 161).

86. Different scholars have categorized this form of genocide in different ways. Leo Kuper and Helen Fine have termed this form of genocide "retributive genocide," arguing that postcolonial plural societies provide the structural base for genocide. See Leo Kuper, Genocide: Its Political Use in the Twentieth Century (New Haven and London: Yale University Press, 1981), chapter four; Helen Fine, Genocide: A Sociological Perspective (London: Sage Publications, 1993), 86-91. Roger W. Smith uses the term "monopolistic genocide" in order to emphasize key questions pertaining to membership and purposes of community and its state. See Roger W. Smith, "State Power and Genocidal Intent: On the Uses of Genocide in the Twentieth Century," in Studies in Comparative Genocide, ed. Levon Chorbajian and George Shirinian (New York: St. Martin's Press, 1999), 5-7. 
87. See Adelman, "Rule-Based Reconciliation," Crocker, "Truth Commissions, Transitional Justice and Civil Society," and Carol A. L. Prager, "Introduction," in Dilemmas of Reconciliation: Cases and Concepts, ed. Carol A. L. Prager and Trudy Govier (Waterloo, ON: Wilfrid Laurier Press, 2003), 1-27.

88. See Charles Villa-Vicencio and Wilhelm Verwoerd, eds., Looking Back, Reaching Forward: Reflections on the Truth and Reconciliation Commission of South Africa (Cape Town, South Africa: University of Cape Town Press, 2000). 